\title{
ALDA LARA E O QUE FALTA FAZER: AS ACHEGAS DOS PERIÓDICOS
}

\author{
ALDA LARA AND WHAT WE STILL HAVE \\ TO DO: THE CONTRIBUTIONS \\ OF NEWSPAPERS
}

Francisco Topa ${ }^{1}$

\section{RESUMO}

Este artigo apresenta os elementos colhidos através da leitura do Jornal de Benguela, em que colaborou Alda Lara, com uma série de materiais em prosa e em verso até agora desconhecidos. Pretende-se assim ilustrar o que ainda nos falta fazer em torno do conhecimento da obra e da personalidade desta figura importante da literatura angolana.

PALAVRAS-CHAVE: Alda Lara; periódicos; literatura angolana.

\section{ABSTRACT}

This article presents the information gathered from Jornal de Benguela, in which Alda Lara collaborated with a series of prose and verse materials hitherto unknown. It is intended to illustrate what we still need to do concerning the work and the personality of this important figure of Angolan literature.

KEYWORDS: Alda Lara; newspapers; Angolan literature. 
Por razões que hoje são mais difíceis de compreender, não tem havido em relação à literatura angolana um cuidado sistemático com a edição de textos. Há poucos anos, a coleção dos 11 clássicos promovida pela União dos Escritores Angolanos consistiu numa republicação pura e simples de edições anteriores, muitas delas contendo erros sérios na fixação das obras. Foi o caso, entre outros, dos dois primeiros volumes, Espontaneidades da minha alma, de Maia Ferreira, e Nga Muturi, de Alfredo Troni. O primeiro copiou até, sem alterações, o prefácio de Gerarl Moser da edição de 1980, esquecendo que entretanto oram publicados vários trabalhos de investigação que esclareceram aspetos importantes da vida e da obra do autor.

Não será esse o caso de Alda Lara, que pôde dispor de uma espécie de curador da sua obra na figura do marido, o também escritor Orlando de Albuquerque. Isso não significa contudo que o seu trabalho esteja isento de reparos, como iremos ver. De resto, as críticas ao escritor e médico surgiram pouco depois da morte de Alda. A 30 de janeiro de 1965, o ABC: diário de Angola assinalou a passagem do terceiro ano do falecimento da autora de "Testamento" e uma das peças (Reis, 1965), que transcrevia um apontamento de Álvaro Reis lido na Emissora Católica Hora Zero, lamentava o contraste entre a fama da poetisa e o conhecimento efetivo da sua obra. Segundo o articulista, "Nunca uma literata angolana teve a rodeá-la um clima de prestígio tão intenso e de admiração tão imoderada." E contudo, notava, “Três anos depois da sua morte, a poesia de Alda Lara está praticamente inédita, por um capricho absurdo e injustificado do seu detentor."

Albuquerque explica os critérios que usou na edição, que parecem aliás inatacáveis: por um lado, tentou respeitar a vontade da autora, que tivera o projeto de editar em livro uma seleção dos seus poemas; por outro, como Alda pensara publicar um segundo volume a partir dos restantes mas faleceu sem indicar os textos a incluir, Orlando de Albuquerque decidiu dar ao prelo "todos (e outros mais que tinha em meu poder) num LIVRO SEGUNDO, procurando, tanto quanto possível, ordená-los segundo a sua antiguidade, citando-lhes as datas de criação, quando existiam." (Lara, s/d, p. 7) Quanto à fixação dos poemas, esclarece o editor que, como "alguns desses poemas sofreram, através dos anos, correcções e alterações, optei sempre pela versão mais recente, arquivando, no entanto, essas diferenças em apêndice no final da obra." (ibid.: 8).

Sem pôr em causa o trabalho do editor de Alda Lara, apresentarei contudo uma série de pequenos contributos para a sua melhoria, resultantes de uma pesquisa em curso a partir da consulta de periódicos. A primeira dessas achegas diz respeito à recolha de textos e constitui sobretudo uma curiosidade: identifiquei no Jornal de Benguela aqueles que serão talvez os primeiros escritos de Alda, dois textos em prosa e dois sonetos. Os primeiros intitulam-se «Natal» (Lara, 1943a) e «Salvé Ano Novo!» (Lara, 1943b) e saíram no final de 1943, quando a autora tinha portanto 13 anos. Como seria de esperar, são escritos de uma adolescente, com alguns lugares-comuns, mas bem redigidos e revelando já a preocupação com o outro que marcará a 
poesia de Lara. O tema principal é a guerra e o seu contraste com os valores do Natal, visível por exemplo na representação da hesitação do Pai Natal: "Mas também ele tem medo de confundir o soar estridente da sereia com o dobrar festivo do sino, e julgando chegado o momento da sua missão, descer à terra e ser recebido por uma chuva de bombas, em exótica saudação." (Lara, 1943a) Ressalta igualmente a preocupação com o efeito do conflito sobre as crianças:

Mas se o medo não entra no interior da infância, eis que a faceta do seu caráter se muda repentinamente! E se outrora a boneca e o carro eram o brinquedo apetecido, hoje a metralhadora, o avião, o tank triunfam em toda a plenitude do seu complexo maquinismo. E a criança é habituada desde pequena à inumerável coleção de monstros que mais tarde aprenderá na escola, serviram para que os homens se esfacelassem uns contra os outros, lutando afinal pela mesma causa...! (Lara, 1943a)

Um pouco menos previsível talvez é a nota nacionalista, ampliando uma ideia difundida pela propaganda do Estado Novo:

Serenamente o sino continua o seu risonho tanger. E a alma desse bronze que as mãos artísticas do homem moldaram, e ao qual a mentalidade com um sopro de imaginação deu vida, signo da voz gritante de uma raça parece dizer:

"Vem Portugal! Estoico povo de heróis que no silêncio e na paz, soubeste tirar do próprio sofrimento a resignação sublime, para um prémio maior!"

E àquela voz Portugal deslumbrado, ressurge das próprias cinzas, e comovido suplicante ajoelha pedindo de novo o presente que há quatro anos o "Pai Natal" tem deixado sempre no sapatinho do seu governo: A Paz! (ibid.)

Quanto aos sonetos, o primeiro saiu pela Páscoa de 1944, quatro anos antes dos primeiros poemas datados incluídos na edição organizada por Orlando de Albuquerque. Introduzindo uma temática que depois assumirá relevância na sua obra futura, Alda apresenta um soneto tecnicamente correto (a acentuação (2)-5-7-10 do v. 9 não constitui uma irregularidade), embora não revele ainda traços de um estilo próprio:

\section{Ressurreição}

da distinta poetisa Alda Barreto de Lara

Já Madalena louca em vão procura

O vulto extinto do Rabi bendito!

Que após três dias, como tinha dito,

Deixara glorioso a sepultura.

E a terra ébria, em gritos de ventura,

Saüdou a quem obedecera Tito!

Dulcíssimo clarão jamais descrito

P'ra sempre aureolou sua figura. 
Milagre! gritava o povo de então.

Milagre! ainda se diz. Ressurreição!...

$\mathrm{E}$ a prece sobe, em ritos de saüdade.

Cordeiro Imaculado... Rei do Mundo,

Por ti, Senhor, p'lo teu amor profundo,

Ressuscita também a humanidade!

Benguela, Páscoa de 1944 (Lara, 1944)

O outro soneto foi publicado no 15 de agosto de 1946, celebrando a figura do governador Manuel Cerveira Pereira, que fundou, em 1617, a segunda Benguela:

\author{
A Manuel Cerveira Pereira \\ Quando Felipe “o Pio" então reinava \\ No Portugal vencido d'anarquia, \\ Por mil razões prudentes não esquecia \\ A velha Angola, em que também mandava. \\ E, assim, Cerveira P'reira o Rei tornava \\ Governador das gentes! Este havia \\ De combater, matar... e Calubia \\ Algures vencer! Benguela se fundava! \\ Valente homem, soldado - audaz guerreiro, \\ O seu génio de déspota, altaneiro, \\ Criou-lhe inimizades sem canseira. \\ Talvez por isso, ao facho da memória, \\ Se esboça sempre unido a tanta glória, \\ $\mathrm{O}$ rosto desdenhoso de CERVEIRA.
}

$11 / 3 / 946$

Alda Lara (Lara, 1946)

Conhecido pela dureza e crueldade, inclusive contra as suas tropas, Cerveira deu um passo importante para a expansão da conquista portuguesa (ou, na época, luso-espanhola) de Angola, dinamizando o comércio de escravos com a abertura de um segundo porto. À semelhança do anterior, o poema não apresenta particulares motivos de interesse, constituindo pouco mais que um exercício escolar.

Para além destes quatro textos, há outros materiais saídos na imprensa com interesse para o estudo de Alda Lara. Entre eles conta-se uma crónica sobre uma companheira de estudos falecida ("In Memoriam (à minha amiga Maria Alice Bordalo Pereira, morta a 25 de Outubro de 1949)", Lara, 1949) e uma entrevista ${ }^{2}$ que concedeu no final de 1952 ao Jornal de Benguela (Martins, 1952), na qual, a propósito da mensagem social da arte, explicita a sua conceção artística: 
Falando nela não quero criar o compartimento estanque da "arte social" com que alguns têm esgrimido por oposição à chamada "arte pela arte". A Arte é só uma. Não pode haver razões de ordem social que limitem a vastidão do universo poético, que lhe cortem as suas possibilidades. Necessário é dar-lhe todas as possibilidades criadoras. Além de que a liberdade é condição essencial de qualquer obra de arte para que ela seja viva. Portanto, o que se exige é que a arte seja autêntica. E porque esta autenticidade requer por sua vez presença dos problemas do cotidiano, coração aberto à hora que se vive, comunhão íntima com os nossos irmãos que lutam, sofrem e cantam, assim nenhuma autenticidade será autêntica fora desta órbita. (Martins, 1952, p. 1)

Mais importante porém é um artigo da própria Alda, saído em 1950 no Jornal de Benguela e intitulado "Acerca de poesia angolana", em que defende, a partir do exemplo de Cabo Verde, uma literatura que exprima a essência angolana, mas sob um prisma regional, na medida em que a autora só concebe estes espaços como parte de Portugal. Depois de afirmar que "A poesia cabo-verdiana é hoje uma realidade., esclarece assim a sua visão sobre a literatura do arquipélago:

Dizer que a poesia de Cabo Verde não é portuguesa é dizer que Cabo Verde não pertence a Portugal. Decerto que em Cabo Verde também se fez "poesia lusíada", embora em muito menor escala do que nas outras colónias - essa que glorifica os heróis da ocupação e os civilizadores. Decerto. Mas o seu tempo passou, e o cabo-verdiano, passados que foram também os feitos dos colonizadores, começou a interessar-se mais pelos aspetos que o cercavam ali na sua própria terra. Daí o seu folclore e a sua poesia. Daí os poetas que falaram dessa terra e dessa raça que haviam sido esquecidos até por eles. (Lara, 04/10/1950, pp. 1 e 8)

Sobre o caso de Angola, cita um poema de Alexandre Dáskalos, acrescentando:

Ninguém poderá impedir que mais cedo ou mais tarde a poesia angolana nasça, como nasceu a de Cabo Verde, e há de nascer a de Moçambique. E dizer que essa poesia, por falar, hoje, menos dos feitos dos colonizadores e mais dos problemas da Terra que todos os dias cercam os poetas angolanos, não é portuguesa, é não querer ver, tal como no caso de Cabo Verde. Porque se Angola é Portugal (e disso ninguém tem dúvidas), a poesia angolana tem de ser incontestavelmente portuguesa, condicionada embora por um clima e por uma raça diferentes. (Lara, 04/10/1950, p. 8)

O remate do artigo é feito com uma citação do conhecido poema "Confiança", de Neto:

[A Nova Poesia de Angola] Será feita com a colaboração 
simultânea da poesia nativa e da poesia lusíada; com poetas brancos, e com poetas que, como Geraldo Bessa Victor, serão negros e cantarão os temas negros, mas não se limitarão a fazer isso apenas, porque é já deles a voz que se ergue para dizer:

As minhas mãos colocaram pedras

nos alicerces do mundo.

Mereço o meu pedaço de pão.

(Agostinho Neto) (Lara, 07/10/1950, p. 7)

A segunda achega relativamente à edição preparada por Orlando de Albuquerque diz respeito à fixação dos textos. Darei apenas um exemplo, confrontando de forma esquemática a versão publicada pelo companheiro de Alda (Lara, s/d: 50) com a do Jornal de Benguela (Lara, 1952), em que o poema apresenta uma datação mais recente:

II

A fruta sazonada é fresca orgia que corre à nossa boca em linfa escura... Mulher! Ergue-te e olha! A toda a altura a breve mão te alcança o novo dia.

Descansa à luz do tempo a face esguia, coberta de vigílias e amargura.

É tua a sede desta terra dura,

Irmã de todo o medo e cobardia...

O preço das traições que te marcaram e quantas dores ocultas te açoitaram, hás-de bebê-lo sem tremer... Imundo,

o vinho deste mosto é sangue e vida! Podes brindar por ti, na hora erguida, e estilhaçar a taça, aos pés do mundo!...

Lisboa, 1950

[Lara, s/d, p. 50]

\section{VINDIMA}

A fruta sazonada é fresca orgia que corre à nossa boca em linfa escura... Mulher! Ergue-te e olha!... a toda a altura a breve mão te alcança o novo dia...

Descansa à luz do tempo a face esguia, coberta de vigílias e amargura.

É tua a sede desta terra dura, irmã de todo o medo e cobardia.

O preço das traições que te marcaram, e quantas dores ocultas te açoitaram há-se bebê-lo sem tremer! Imundo,

o vinho deste mosto é sangue e vida... Podes brindar por ti na hora erguida, e estilhaçar a taça aos pés do mundo!

(II poema da "Trilogia do Outono")

Lisboa, outubro de 1952.

[Lara, 1952]

Dir-se-á que as variantes são menores, o que é verdade, sendo certo porém que a última versão, a do Jornal de Benguela, deveria ter sido a adotada, o que sugere que há que rever o conjunto da obra da autora à luz de uma pesquisa sistemática em torno dos materiais que a transmitem. Só assim poderemos corrigir, pelo menos ao nível textual, a afirmação de Alfredo Margarido: “A poesia de Alda Lara está incompleta. É, antes de mais, uma poesia que vive no mundo da infância ou de uma primeira fase da adolescência." (Margarido, s/d, p. 14). 


\section{REFERÊNCIAS BIBLIOGRÁFICAS}

LARA, Alda. Natal. Jornal de Benguela. 24/12/1943, p. 3.

LARA, Alda. Salvé Ano Novo! Jornal de Benguela. 31/12/1943, p. 6.

LARA, Alda. Ressurreição. Jornal de Benguela. 09/04/1944, p. [1].

LARA, Alda. A Manuel Cerveira Pereira. Jornal de Benguela. 15/08/1946, [penúltima página].

LARA, Alda. In Memoriam (à minha amiga Maria Alice Bordalo Pereira, morta a 25 de Outubro de 1949). Jornal de Benguela. 12/11/1949, p. 3.

LARA, Alda. Acerca de poesia angolana. Jornal de Benguela. 04/10/1950, pp. 1 e $8 ; 07 / 10 / 1950$, p. 7.

LARA, Alda. Vindima. Jornal de Benguela. 15/12/1952, p. 1.

LARA, Alda. Poemas. $4 .^{\text {a }}$ ed. Porto: Vertente, s/d.

MARGARIDO, Alfredo. Esboço de interpretação da poesia de Alda Lara. Mensagem. Lisboa: Casa dos Estudantes do Império. Ano XIV, 2, (s/d).

[MARTINS, Leston]. O que pensam os Novos: Uma entrevista com Alda Lara. Jornal de Benguela. 22/12/1952, pp. 1-2.

REIS, Álvaro. «Uma obra poética de que se fala muito mas que se conhece pouco». ABC: diário de Angola. Luanda, 30/01/1965, p. 3.

Recebido para avaliação em 30/09/19 Aprovado para publicação em 24/01/20

\section{NOTAS}

1 Professor Associado com Agregação da Faculdade de Letras da Universidade do Porto, Portugal. Leciona nas áreas de Literatura e Cultura Brasileiras, Crítica Textual, Literaturas Africanas de Língua Portuguesa e Literaturas Orais e Marginais.

2 Que edito integralmente no Apêndice.

3 Também transcrito no final do artigo.

\section{APÊNDICE}

Jornal de Benguela, 04/10/1950, p. 1 e 8, 07/10/1950, p. 7

\section{Acerca de Poesia angolana}

\section{Por Alda Lara}

Dizia há tempos o Prof. Antero de Seabra, numa das suas palestras radiofónicas sobre "Os povos do Ultramar e a sua cultura":

Os cabo-verdianos são sem dúvida portugueses. Mas portugueses influenciados por um clima diferente, sentindo de maneira diferente, solicitados por problemas diferentes. Portugueses 
limitados pela sua condição de filhos de dois continentes; pela sua estrutura psicológica, onde se funde o lirismo do branco e a sensualidade do negro; pelas necessidades do ambiente onde nascem, crescem e morrer. Numa palavra, portugueses condicionados pelo clima e pela terra de Cabo Verde.

Daí a sua poesia própria, os seus cantares, as suas danças. Dizer que a poesia de Cabo Verde não é portuguesa, é colaborar numa falsidade, é não ver que não havia possibilidades de tirar o cabo-verdiano da sua terra e do meio da sua gente, para fazer poesia. Ela está precisamente aí, - onde se dançam as mornas, onde se perdem as crioulas, onde se sofrem as secas... Por isso e por tudo também, a poesia cabo-verdiana, senhora embora de uma feição própria, e característica, é incontestavelmente poesia portuguesa.

Mais ou menos foi isto que o Prof. Antero de Seabra disse. Disse-o com a certeza e a convicção que a verdade empresta àqueles que dela se servem. E ninguém ousará duvidar das opiniões que com tanta coerência e conhecimento fez.

A poesia cabo-verdiana é hoje uma realidade. Desde os tempos da Certeza aos nossos dias com Claridade, ela se tem vindo a afirmar cada vez mais.

Fixada na terra, de olhos voltados para os problemas rácicos e para todos os problemas que cercam o pequeno arquipélago, ela fez-se com poetas como Jorge Barbosa, Eugénio Tavares e outros.

Dizer que a poesia de Cabo Verde não é portuguesa é dizer que Cabo Verde não pertence a Portugal. Decerto que em Cabo Verde também se fez "poesia lusíada", embora em muito menor escala do que nas outras colónias - essa que glorifica os heróis da ocupação e os civilizadores. Decerto. Mas o seu tempo passou, e o cabo-verdiano, passados que foram também os feitos dos colonizadores, começou a interessar-se mais pelos aspetos que o cercavam ali na sua própria terra. Daí o seu folclore e a sua poesia. Daí os poetas que falaram dessa terra e dessa raça que haviam sido esquecidas até por eles. Poetas que, como António Nunes, nascido e criado em terra cabo-verdiana, filho embora de pais brancos, pôde fazer poemas tão belos como este:

Maninho di nha Noca na ânsia de ver o Mundo fugiu inda menino a bordo dum vapor.

Nha Noca entreabre a porta e põe-se a olha o mar.

- O Mar é a imagem de Maninho ausente...

Passam mulheres com latas de água à cabeça.

Miséria na Ilha, miséria nas Ilhas: a chuva não veio, os vapores com a guerra, quase não tocam no porto e há tanta gente a morrer de fome!

Bem fez o Maninho que fugiu para longe...

Um galo canta.

Nha Noca olha o Sol que já vai alto e vai cochir o milho prá cachupa... 
Que choro é este na casa di nha Noca?

Maninho di nha Noca que morreu no mar...

$O$ vapor foi afundado quando ia não sei para onde...

Zé di nho Pedro é que mandou contar...

Nha Júlia

vê interpor-se a imagem de Maninho

quando da última vez

III

Deslumbrados

Os rapazes do liceu ficaram pensando

nas terras de longe...

Cada dia um porto

e entre fumos de cigarros e cálices de bebidas

uma mulher nos braços...

No céu

uma estrela passa rápida.

O som dum violão dilui-se na distância...

Faz-se silêncio na noite.

(Do livro Poemas de longe)

Dizer que esta poesia, a poesia cabo-verdiana, não é portuguesa, é não ter olhos para ver. É não compreender que passados os anos da descoberta e de ocupação, o cabo-verdiano, embora com os braços estendidos para a Metrópole, tinha forçosamente que descobrir a sua alma em Cabo Verde, a terra em que nascera, crescera e vira morrer os seus avós. A sua terra.

E isso mesmo, mais não é afinal que o resultado do Progresso, provocado ainda e sem dúvida alguma pela Colonização Portuguesa.

Visto o problema com a lente comparativa da poesia cabo-verdiana, aquela que caminha hoje na vanguarda das poesias do Ultramar, e sobre a existência da qual já ninguém põe dúvidas, passemos ao caso que mais interessa - o da poesia angolana.

Quanto Angola se adiantou em relação a Cabo Verde sob o aspeto industrial e piscatório, mercê das suas fantásticas possibilidades, quanto se atrasou em relação aos problemas intelectuais, e principalmente em relação à poesia. Talvez que esse facto mesmo fosse o causador do quase marasmo em que a poesia angolana se tem mantido até hoje. Marasmo condicionado pela facilidade de vida, pelo ambiente de fartura e bem-estar que em Angola se contrapõe à seca e à fome de Cabo Verde.

Esta colónia sentiu, desde o princípio, necessidade espiritual duma poesia sua que falasse das desditas do seu povo, lutando com dificuldades de toda a ordem e ansiando sempre por se libertar e partir para um mundo diferente. Necessidade espiritual, impulsionada por uma necessidade material. 
Com Angola nada disso aconteceu. Tinha tudo. Era rica e farta. Ninguém viu que essa fartura tinha a alicerçá-la algo de ignorado: refiro-me ao NEGRO, aquele de quem Coelho Neto disse "que se lhe deve erguer um monumento"! Na verdade, este elemento tão ignorado, e por vezes tão incompreendido, ajudara o branco a erguer as casas, cultivara-lhe os campos, embalara-lhe os filhos. Mas isso ninguém viu. E a poesia foi continuando a cantar os heróis da ocupação e os civilizadores, esquecendo esses outros heróis ignorados, esquecendo os problemas rácicos levantados por mil e um acidentes, esquecendo a beleza quase sobrenatural de uma Colónia que se fizera Mulher sem ninguém dar conta, - até um dia. Até um dia os novos aparecerem e dizerem que era preciso fazer uma "nova Poesia”. A poesia que falasse na mulher negra não apenas como beleza sensual, mas também como Mãe. Que falasse não só dos poentes africanos e da beleza da selva, mas que falasse também da tragédia daqueles brancos que quiseram partir um dia em busca de uma civilização maior, e tiveram que ficar de braços pendentes à borda de um cais, confundidos com os carregadores negros que todos os dias transportam nos ombros suados as mercadorias que correm o mundo.

$\mathrm{E}$ os novos diziam mais, que nunca ninguém tinha dito. Que era preciso que todos se unissem, brancos, negros e mestiços para conquistarem de novo a Terra. Que era preciso, sim, explorar o solo, lançar as redes, povoar todas as extensões quilométricas do solo angolano que esperam ainda abandonadas, mas que tudo isso deveria ser feito com um amor também novo, desinteressado e superior a todas as vicissitudes materiais que daí pudessem advir. Amor à terra por ela própria e por mais nada. Esse amor que os faz dizer pela boca de um dos maiores poetas angolanos da nossa geração:

Ah, Angola, Angola, os teus filhos escravos, nas galeras correram as rotas do mundo... Sangrentos os pés, os pés por pedregosos trilhos, vinham do Sertão, lá do Sertão, lá bem do fundo...

A vida, a terra, o lar, tudo distante...

De tão distante, tudo tão presente, como na floresta a noite... Ao longe, o brilho duma fogueira acesa, acesa no teu corpo que de tão sentido já não sente.

A América é bem teu filho, arrancado à força do teu ventre!

(Alexandre Dáskalos)

Depois disto, dizer que "a poesia lusíada de Angola é a única que nos vários concursos locais se deve admirar e estimular”, como afirmava há tempos o snr. major Mateus Moreno, é cometer um erro de humanidade. Seria necessário criar um viver fictício àqueles poetas que não se pudessem 
deslocar à Metrópole ou então cercear-lhes a inspiração. Seria criar uma dívida para com o Futuro de Angola.

Ninguém poderá impedir que mais cedo ou mais tarde a poesia angolana nasça, como nasceu a de Cabo Verde, e há de nascer a de Moçambique. E dizer que essa poesia, por falar, hoje, menos dos feitos dos colonizadores e mais dos problemas da Terra que todos os dias cercam os poetas angolanos, não é portuguesa, é não querer ver, tal como no caso de Cabo Verde. Porque se Angola é Portugal (e disso ninguém tem dúvidas), a poesia angolana tem de ser incontestavelmente portuguesa, condicionada embora por um clima e por uma raça diferentes.

Por outro lado não me consta que as poucas tentativas de poesia nativa que os nossos poetas têm feito, sejam desconcertos de nativismo brasílico, como dizia ainda o snr. major Mateus Moreno. Antes fossem, que do Brasil sai hoje uma das melhores poesias do Mundo. Basta citar nos nossos dias Cecília Meireles e Jorge de Lima, para não falar em Olavo Bilac, Castro Alves e outros.

Mas não creio que a poesia angolana venha a ser uma poesia brasílica, porque lhe encontro riqueza de temas e matéria-prima suficiente para se libertar. Todavia não seria de admirar que a poesia angolana se sentisse influenciada pela do Brasil. Motivos de ordem vária o determinam. Basta citar as condições sociais e geográficas, que são as mesmas tanto para Angola como para o Brasil, e a facilidade de comunicações que entre uma e outro se mantiveram com frequência e normalidade. Além de que também a poesia portuguesa foi influenciada durante algum tempo pela poesia francesa, sem que isso lhe tivesse tirado o valor ou afetado a individualidade.

Não admira, pois, que a poesia angolana venha a sofrer a influência do Brasil. Mas digo influência, nunca identificação.

E para terminar, não quero deixar de citar, por me parecerem de interesse, as palavras que na revista Vértice, de setembro de 1948, Orlando de Albuquerque [escreveu]: "Deles [referindo-se aos novos poetas angolanos] é já também aquele volver de olhos para a Vida, e para os homens que nela andam. Deles é do mesmo modo a humana simpatia pela negra que eles começam de compreender. Não podemos deixar de citar aqui Geraldo Bessa Vítor, um mestiço negro, que, embora lhe não assista a força poética que caracteriza alguns dos jovens da nova poesia de Angola, tem no entanto o mérito de ter sido o primeiro a transportar para a poesia os temas verdadeiramente negros. Não queremos também terminar este despretensioso trabalho sem indicar uma das fontes em que uma verdadeira poesia angolana terá que forçosamente ir beber. Trata-se da poesia nativa - da poesia dos negros. A sua contribuição não será por certo esquecida. Disso temos a certeza, ao auscultar os novos rumos da nascente poesia angolana, a poesia que lentamente sentimos nascer"...

Isto, o que Orlando de Albuquerque disse. Isto, o que todos nós sentimos. 
Sim! A Nova Poesia de Angola será feita desse "volver de olhos" e dessa "humana simpatia". Será feita com a colaboração simultânea da poesia nativa e da poesia lusíada, com poetas brancos, e com poetas que, como Geraldo Bessa Vítor, serão negros e cantarão os temas negros, mas não se limitarão a fazer isso apenas, porque é já deles a voz que se ergue para dizer:

As minhas mãos colocaram pedras nos alicerces do mundo.

Mereço o meu pedaço de pão.

(Agostinho Neto)

E quando isto tiver sucedido, então a poesia angolana, a verdadeira, surgirá pela mão dos NOVOS que a souberam mais adivinhar que descobrir. E ninguém cerceará esses novos, porque a causa deles é justa e humana, e além de tudo Portugal nunca limitou as possibilidades dos que lhe pertencem.

Felizes, digo eu, daqueles que puderem assistir a isso, porque lhes será dado presenciar um dos mais belos movimentos que a "História da Poesia Portuguesa Colonial” registará.

Lisboa, setembro de 1950

Jornal de Benguela, 22/12/1952, p. 1-2

\section{Uma entrevista com Alda Lara}

Alda Lara é uma angolana de gema, uma benguelense que em circunstância alguma - mesmo lá longe, na Metrópole, onde reside há anos para realizar a aspiração de se formar em Medicina - esquece nunca o seu torrão. É, além disso, uma talentosa poetisa, cuja vocação para as letras se revelou bem cedo, quando ainda aluna do Colégio Paula Frassinetti, de Sá da Bandeira, vocação que veio, mais tarde, a ser plenamente confirmada. A sua presença entre nós proporcionou-nos, por intermédio do nosso companheiro de trabalho Leston Martins, a iniciativa de abrir um inquérito sobre $\mathbf{O}$ que pensam os novos - inquérito que esperamos prosseguir em breve - sendo-nos muito grato inserir nesta edição o seu depoimento.

O que define um povo é o seu grau de cultura, e este está dependente da sua arte. Por isso, a arte mostra o grau de civilização e de progresso de um povo. Supor-se que a arte é apenas extensiva a uma meia dúzia de indivíduos é erro crasso. Ela pertence a todos, indistintamente, e a todos deverá ser extensiva. Mesmo o artista que não se faça compreender do público anónimo, falseará a sua missão de artista. Assim, tanto mais o povo compreenderá a mensagem artística quanto mais ela tratar dos problemas que lhe dizem respeito. 
E debaixo deste ponto de vista, mas poucas conversações que tivemos com Alda Lara, em que, entre tantos assuntos a arte foi evocada também, a arte moderna, os seus rumos, a sua finalidade, a futura verdadeira cultura angolana dirigida num sentido mais amplo e, enfim, de tudo o que estivesse relacionado com cultura e arte, recolhemos alguns apontamentos de interesse, baseados em conceitos desta jovem poetisa.

Alda Lara, isto como esclarecimento aos que desconhecem a sua biografia, é natural desta cidade e ultima em Lisboa o curso de Medicina. Tem 22 anos (aqui fica a anotação!...) e veio até nós por uns escassos dias, sentir com os olhos e com o coração as recordações que se estavam esfumando. Depois terá de regressar, para quando voltar definitivamente para o seu rincão natal melhor e mais conscienciosamente poder servi-lo com uma obra vasta e humana.

A sua obra, como ela própria confessa, está apenas começada. Mas chegará ao fim. Terá de chegar ao fim. Não acreditamos que esta jovem que desfia rosários de esperança e de humanidade e que coloca em tudo um entusiasmo exaltado e moço, que confia cegamente no futuro, deixe ficar no caminho folhas dispersas, perdidas, de uma obra que será enorme.

Alda Lara diz que considera a arte como "a mais elevada expressão do pensamento".

Depois com o entusiasmo que tanto a caracteriza, esclarece:

- ... e quando digo pensamento e não sentimento quero significar com isto que não a considero espontânea. Mesmo quando parece sê-lo, pela realização imediata de um estado de espírito especial, a arte é sempre mais um ato do que uma inspiração. Porque antes de chegar às fibras do sentimento o "choque" que provocará a obra de arte, já o raio do pensamento iluminou por si só todo o caminho; muitas vezes mesmo sem o nosso conhecimento, mas apenas do subconsciente que do fundo misterioso nos orienta.

E continua no seu esclarecimento:

- É claro que aqui teremos de considerar ainda o problema do rigor da forma. Assim é que toda a obra de arte, que foi um ato, deverá ser sempre também um ato inspirado, digo, com a profunda consciência dos seus deveres estéticos, sem a qual não haverá "obra artística" no pleno sentido do termo.

Jean Cassou afirmou a respeito da poesia, que o seu fim primordial é "explicar o homem, acompanhá-lo, exaltá-lo no decurso da sua prodigiosa ascensão". Assim também para a Arte em geral. Ela hoje mais do que nunca tem por finalidade "dar força ao homem e permitir-lhe agir sobre o mundo". Estabeleço assim que a finalidade da arte é eminentemente social, mesmo quando pessimista. (O caso de "A 25. ${ }^{\text {a }}$ Hora"). A este pessimismo chamou René Bartel pessimismo tónico.

Mas voltemos à mensagem social da arte. 
Falando nela não quero criar o compartimento estanque da "arte social" com que alguns têm esgrimido por oposição à chamada "arte pela arte”. A Arte é só uma. Não pode haver razões de ordem social que limitem a vastidão do universo poético, que lhe cortem as suas possibilidades. Necessário é dar-lhe todas as possibilidades criadoras. Além de que a liberdade é condição essencial de qualquer obra de arte para que ela seja viva. Portanto, o que se exige é que a arte seja autêntica. E porque esta autenticidade requer por sua vez presença dos problemas do cotidiano, coração aberto à hora que se vive, comunhão íntima com os nossos irmãos que lutam, sofrem e cantam, assim nenhuma autenticidade será autêntica fora desta órbita. Toda a obra de arte tem hoje a finalidade de produzir uma alegra e uma força, capazes de irem de encontro [sic] aos maiores sofrimentos seja qual for a época e o tempo em que eles se situem. Assim todo o poeta de hoje que nos aparece apenas com o seu lirismo e o seu processo interior, completamente alheio aos problemas que nos cercam e nos submergem mais e mais, trai a sua missão.

- Quer dizer então que não nega o lirismo aos artistas que fazem arte social?

- Não. Não nego. Eu disse apenas com o seu lirismo... repare. Também o autor de "La rose et le réséda", o grande Aragon, publicou um livro de poemas de amor que dedicou à mulher (Les yeux d'Elsa) e nem por isso deixou de ser o poeta eminentemente social que conhecemos. É que o seu processo interior não é apenas o amor à mulher, mas também Amor a todos os homens, em toda a sua obra.

- Mas creio que essa "expressão de pensamento" que deverá ser viva, autêntica, que esse ato é o que diferencia a arte moderna de qualquer outra arte. Julgo que acredita no futuro da arte moderna e que crê nela, pois já esclareceu, se me não engano, a sua finalidade.

- Por arte moderna estou entendendo aquilo a que por sucessão ao "modernismo" chamaríamos talvez o quê? futurismo... Não?

- Certamente...

- Sim! Acredito nas possibilidades futuras da arte moderna. E acredito porque é necessário que a cada ato deste longo drama de evolução, suceda o seguinte, e na própria altura. Ora o público já começa a bater os pés e a assobiar. Quer o ato seguinte. Não tardará que ele suba à cena. De resto parece não haver dúvida de que o ponto fundamental de todo o pensamento moderno é este; "o da consciente instabilidade de tudo".

Assim vivendo numa época que é forçosamente de transição, sabemos melhor do que ninguém que não podemos parar. É por isso que acredito nas possibilidades da arte moderna...

\section{Não existe ainda uma cultura angolana embora já se vislumbrem tenta- tivas...}

- E já que estamos tratando de arte e de arte moderna, tem alguma opinião já formada a respeito do que se diz cultura angolana? Ela existe na verdade? 
- Não há cultura angolana, doa embora aos nossos corações afirmá-lo tão peremptoriamente. E por cultura angolana entendemos aquela cultura local, solidamente enraizada no meio, alimentando-se de caracteres próprios embora sem perda de um vasto sentido humano. Aquela cultura que, eivada assim de um profundo sentido de humanidade, está todavia intimamente ligada aos problemas locais, aos dramas da terra - aquela onde as conquistas formais das correntes modernistas se casam com o folclore local ou até nativo.

É essa cultura que ainda está por fazer. Os nossos poetas, principalmente, têm-se esquecido de que vivem com os pés fincados nesta terra e que é dela que têm de receber a seiva que os alimentará para a compreensão de tudo o que está para além. Mais longe então - o vasto sentido de humanidade ressumando de uma obra "nossa"... como um verdadeiro aperfeiçoamento. Mas a fazê-lo, teremos de começar pelo princípio. É ainda e sempre o Brasil que evoco como exemplo. Foi dos problemas da terra que Jorge de Lima se içou aos problemas do mundo. Foi do seu pequeno drama brasileiro que ele caldeou o drama da Humanidade na sua obra. Assim connosco.

- Uma vez que evoca como exemplo o Brasil e como com este país poderemos estabelecer um paralelismo e eles têm uma cultura caracteristicamente sua, acredito que vê possibilidades de se criar uma cultura angolana, uma vez que para si ela não existe?

- Sim, vejo possibilidades de se criar essa cultura...

- Desculpe-me interrompê-la. Mas quero fazer uma pergunta que interessa, uma vez que estamos a debater o problema. Há algumas tentativas para essa cultura?

- Há Grupos de novos que vim encontrar já, quando, confesso, nada esperava. Grupos que hoje são tímidos mas que amanhã serão valores conscientes e humanos.

Cito a Associação dos Naturais de Angola, com o seu Departamento Cultural, e todos os elementos que dela irradiam para os pontos mais diversos e afastados, fiéis ao pensamento de uma cultura verdadeiramente angolana.

\section{O caso da revista Momento}

- Agora ainda dentro do campo cultural, fale-me do Momento. Diga-me por que se publicaram apenas dois números. Fale-me das causas que originaram a queda dessa revista literária que prometia marcar uma presença "colonial" forte e segura; dessa maravilhosa oportunidade que se perdeu.

- Momento foi uma aventura, um sonho louco, por agora posta de parte. Mas não perdida definitivamente. A esperança é a coragem dos novos. Quando tudo parece ter acabado para sempre, a esperança salva-nos. O grupo que lançou o Momento dispersou-se inesperada e bruscamente. Uns foram para a tropa, outros transferiram-se para Lisboa. Os casos de Orlando de Albuquerque e do Agostinho Neto. Separados por muitos qui- 
lómetros sem poderem fazer um trabalho em conjunto, a ideia tinha que forçosamente soçobrar. Além de tudo isto, ainda a questão financeira. Por tudo o Momento teve de parar.

Até quando? Não sabemos. Estamos à espera que nos saia a sorte grande, ou então, que a esperança faça o milagre...

Momento foi talvez a oportunidade única dos coloniais poderem vincar com garra o seu apelo. (Isto é que verdadeiramente mais nos dói...) Ela perdeu-se, mas esperamos por outra. E ela virá com certeza, mesmo que demore.

\section{O problema negro na literatura portuguesa}

- E que me diz da obra que vocês editaram, desse malogrado jovem João B. Dias, - Godido?

- Esta obra foi editada por três almas de boa vontade. O Orlando, eu e o Evaristo. Na hora em que entrámos no quarto do falecido João Dias para salvar meia dúzia de papéis rabiscados nervosamente, de uma desinfeção impiedosa, mal sabíamos que, com esse ato, dávamos um passo em frente nos caminhos da literatura colonial - porque Godido é o único livro daquele que havia de ser o primeiro escritor colonial, se a morte o não tivesse impedido. Muitos romances "coloniais" têm vindo a lume, alguns com interesse que não regateio - como descritivos ou narrativas de interesse folclórico ou regional - direi mesmo histórico - mas nesses romances o problema humano está abafado. Está subjugado pela descrição. A maior parte das vezes está mal tratado, isto é, tratado com incompreensão e falta de identificação. E isto é assim por maior que seja a nossa boa vontade de escritores brancos. Ainda estamos longe de compreender o problema negro que é, no final de contas, o verdadeiro problema colonial, de maneira que o possamos transmitir integralmente, sem facciosismos ou deturpações. Somos de uma geração demasiado recente. Talvez só na geração vindoura ou ainda na outra, se modifique para melhor.

Ora com João Dias - o escritor negro - tudo se passou ao invés. Ele "deu-nos tudo" porque tinha tudo em si. Daí a garra literária de Godido e a sua força. Daí a sua inteira e fecunda sinceridade.

- Mas não acha, Alda, que o Godido é uma mensagem pessimista? E o pessimismo só irá servir para afundar a resolução de qualquer problema.

- Não contesto. Mas esse é o tal "Pessimismo tónico" que citei atrás. Por isso nós consideramos Godido o primeiro trabalho verdadeiramente colonial e deploramos a perda do seu autor ainda bastante jovem e que seria o maior contista da nossa geração.

\section{A necessidade de "contacto" com o seu meio, dos estudantes ultramari- nos emigrados para a Metrópole}

E para fugirmos às recordações tristes que nos poderiam trazer à memória a evocação desse jovem moçambicano que a Morte implacavelmente ceifou na bela idade de 23 anos, inquirimos de Alda Lara, abandonando 
desta vez o campo artístico-cultural, das necessidades e anseios principais dos estudantes ultramarinos na Metrópole. E com um sorriso bom e amigo, ela disse-nos:

- Acho que a maior necessidade dos estudantes ultramarinos na Metrópole, como os daqui, é o contacto.

Os estudantes do Ultramar precisam de ir à Metrópole para contactar, para ver, para julgar. Só para conhecerem que o mundo não acaba na Baía de Luanda ou no porto do Lobito. O mundo é maior do que tudo e que há homens por todo esse mundo além que vivem como nós, que lutam como nós e amam como nós.

Por outro lado os estudantes do Ultramar na Metrópole precisam de vir. E pela mesma razão: para ver, para julgar, para recordar. Hoje um curso superior dura seis anos na melhor das hipóteses, 7, 8, 9 anos é a média em que o colonial permanece na Metrópole sem atendermos que estes anos ocupam a melhor época de formação de um indivíduo, dos 18, 19 anos aos 26, 27. Devemos concluir com isto que esse indivíduo faz a sua formação longe da terra que o viu nascer e para onde, logicamente, regressará. Longe, portanto, faz a sua formação, alheio a todos os problemas da sua terra, os problemas com que amanhã, inevitavelmente, se irá chocar. E isto é importantíssimo... Os estudantes ultramarinos nunca deveriam permanecer afastados da sua colónia por mais de dois anos, o máximo três. Deveriam vir. Não perderiam assim a comunhão com os problemas que serão amanhã seus. Além de que esses problemas, na sua ausência, ampliaram-se, modificaram-se, ou despareceram. E para os sentir sempre, é preciso antes de tudo o mais o tal contacto. Longe, tudo se esbate e se complica. Tudo se esquece mau grado o esforço que façamos, mas porque as possibilidades financeiras escasseiam à maior parte dos colonos com filhos a estudar na Metrópole, o estudante colonial permanece aqueles 8 ou 9 anos longe da sua terra. E ao fim desse longo tempo, e mais por isto do que por qualquer outro motivo, ele tornou-se um desadaptado, um estranho ao local que o viu nascer. E só um grande esforço, uma vontade superior o integrará vivamente, sinceramente no meio para o qual regressa. Por outro lado, os novos de cá empobrecem à falta de incitamento. Estiolam, param para sempre se uma viagem à Metrópole os não bafeja, precisamente por essa falta de contacto e porque em matéria de cultura ainda temos tudo para fazer.

E para terminar estes apontamentos colhidos em várias conversações que tivemos com esta poetisa-estudante deixaremos aqui um alvitre seu que esperamos seja uma realidade:

- Seria uma medida utilíssima e que viria beneficiar todos os estudantes tanto de cá como de lá, para um mais fácil intercâmbio-contacto entre eles, a redução de 50\% nas passagens para estudantes. Estaríamos nós sempre na nossa terra, assim como os das províncias estariam na Metrópole. E tudo seria mais fácil. 